\title{
Land Use Planning for Hillside Development Using GIS Based Analytic Hierarchy Process
}

\author{
Seema SAHDEV ${ }^{*}$, Manish KUMAR 1 \\ ${ }^{*}$ Corresponding author \\ ${ }^{1}$ University of Delhi, Kalindi College, Department of Geography, Delhi, INDIA \\ E-mail: seemasahdev@yahoo.com, manish.ks1@gmail.com \\ DOI: $10.24193 /$ JSSPSI.2020.6.04
}

https://doi.org/10.24193/JSSPSI.2020.6.04

K e y w o r d s: Geographic Information System, Pairwise Comparison Matrix, Analytic Hierarchy Process, Site Suitibility, Spatial Decision Support Systems

\begin{abstract}
A B S T RA C T
This paper discusses the process of selection of suitable sites for built-up area development in the lesser Himalayan terrain of Kumaun region in India. This process involves complex steps and handling multiple physiographic and socio-economic factors in order to achieve land suitability. The proposed approach of this study is to provide a framework for integrating the strengths of geographic information system (GIS) and the pairwise comparison matrix known as analytic hierarchy process (AHP) to obtain the most appropriate spatial solution for decision-makers. Thus, Bhikiyasen Block of district Almora, Kumaun Himalaya (India) was considered for mapping the potential sites for the future built-up area development. For this purpose, Cartosat 1 satellite data was used to generate various thematic layers using ArcGIS software. Seven parameters (slope, road proximity, land use/cover, land value, geological formation, drainage proximity and orientation of slopes) were analysed for site suitability and land evaluation. The thematic maps of these criteria were standardized using pairwise comparison matrix and weight for each criteria was generated based on their importance. These criteria and weights ultimately helped in preparing the final land use planning of the area under study. In this paper, the integrated approach of GIS and AHP is showcased as a major contribution towards the development of effective spatial decision support systems (SDSS). This study also provides a new approach for decision-makers in order to reduce future environmental hazards on hillside development.
\end{abstract}

\section{INTRODUCTION}

A rapid build-up of development towards hillsides is one of the critical issues of land use planning and management. This leads to various environmental problems such as landslide susceptibility, soil erosion, deforestation, etc. In order to address these alarming issues, the identification of suitable sites is inevitable (Kumar and Shaikh, 2012) and particularly in the case of hilly areas where slope becomes a major factor. Site suitability analysis provides most suitable areas because some elements are more important than others in determining the best locations.

One of the most successful and widely used approaches, which reduces substantial time as well as effort, is the pairwise comparison method developed by Thomas Saaty (1980) also called AHP. It is one of the methods of multi-criteria decision analysis (MCDA) (Malczewski, 1999). The AHP is a decision analysis technique used to examine complex multi-attributed alternatives with conflicting objectives among multiple players. This method is based on three principles: 
decomposition, comparative judgment and synthesis of priorities.

The decomposition principle requires that the decision problem be decomposed into a hierarchy that captures the essential elements of the problem. In developing the hierarchy, the top level is the ultimate goal of the decision at hand (e.g. select the best site for a built-up development). The hierarchy then descends from general to more specific until a level of attribute is reached. This is the level against which the decision alternatives of the lowest level of the hierarchy are evaluated. Typically, the hierarchical structure consists of four levels: goal, objectives, attributes and alternatives. The alternatives are represented in GIS databases. Each layer contains the attribute values assigned to the alternatives and each alternative (e.g. cell or polygon) is related to the higher-level elements (i.e. attributes). The attribute concept links the AHP method to GIS-based procedures.

The principle of comparative judgement requires the assessment of pairwise comparisons of elements within a given level of the hierarchical structure with respect to their parent in the next-higher level. The procedure greatly reduces the conceptual complexity of the decision-making since only two components are considered at any given time. Because the pairwise comparison procedure can be employed only for a relatively small number of elements at each level of the decision hierarchy, it can only be applied to problems involving a relatively small number of alternatives. When a large number of alternatives are considered, the AHP procedure is terminated at the attribute level and the attribute weights are assigned to the attribute map layers and processed using GIS. This approach is also referred to as spatial AHP (BanaiKashani, 1989; Eastman et al., 1993; Siddiqui et al., 1996). The synthesis principle takes each of the derived ratio-scale local priorities in the various levels of the hierarchy and constructs a composite (global) set of priorities for the elements at the lowest level of the hierarchy (i.e., alternatives).

In general, pairwise comparison is made to choose the most suitable one from a given number of alternatives; but this process also has errors and limitations. And this is because the capacity of the human brain does not allow evaluating each and every given alternative, and, as a result, selection is narrowed down to a few. Though this reduces the human intervention and makes the process extremely simple, the rationality of the process based upon intuitive selection may produce unwanted results, thereby choosing the wrong alternative and overlooking the best solution. In order to avert these types of errors, the idea of AHP's pairwise comparison was introduced, which involves pairwise comparison from the very initial stage, when all the available alternatives exist. That is, pairwise comparison of all available alternatives and 30 not limiting the domain of decision-making process to only the selected ones. That is why pairwise comparison using AHP is more rational, more scientific and considerably advantageous (Kinoshita, 2005).

The AHP has recently gained much attention due to its ability to deal with the multiple factors required in most GIS site suitability analyses. The primary popularity of this method is due to users with a non-mathematical background, who are provided with steps to handle complex criteria for getting the results. Recent developments in GIS have led to significant improvements in its capability for decision-making processes in land allocation and environmental management, among which Multi Criteria Evaluation (MCE) is one of the most important procedures (Janssen and Rietveld, 1990; Burrough et al., 1992; Jankowski, 1995). GIS enables computation of criteria, while a Multicriteria Decision Making (MCDM) can be used to group them into a suitability index. Following a similar approach, Liu et al. (2007) built up an integrated GIS-based analysis system for land-use management of lake areas in urban fringe in central China and AHP method was adopted to derive weights for the evaluating model. GIS and AHP were also used together for land suitability analysis for urban development in the studies conducted by Aly et al. (2005), and Li et al. (2006). Eastman et al. (1993) produced a land suitability map for an industry near Kathmandu using IDRISI (a raster GIS) and AHP. Pereira and Duckstein (1993) have used MCDM and raster GIS to evaluate a habitat for endangered species. Kumar et al. (2014) has compared the methods of weighting assessment techniques including the ranking, rating, pairwise comparison, and trade-off analysis and explained and described about its integration with GIS based MCDM for evaluating suitable sites for urban development. Kumar and Biswas (2013) has dentified potential land development sites for urban development in the Shimla Municipal Area, India using GIS and multi criteria evaluation technique. In general, recent studies have indicated that the combined use of these technologies can support multi-level and hierarchical integrated analysis on human activities, resources and environment.

\subsection{Study Area}

The study area, namely the Bhikiyasen Block (Fig. 1), lies in the lesser Himalayan terrain of Kumaun region and it is one of the eleven blocks of District Almora of the Uttarakhand state, which extends between $29^{\circ} 33^{\prime} 17^{\prime \prime}$ to $29^{\circ} 49^{\prime} 22^{\prime \prime} \mathrm{N}$ latitude and $79^{\circ} 13^{\prime}$ $34^{\prime \prime}$ to $79^{\circ} 23^{\prime} 48^{\prime \prime} \mathrm{E}$ longitude, encompassing an area of $201 \mathrm{~km}^{2}$. The mean relief height of the Bhikiyasen Block is $1217 \mathrm{~m}$, varying between $690 \mathrm{~m}$ to $2010 \mathrm{~m}$ above mean sea level. Cool temperate climatic conditions are prevalent in the region. 


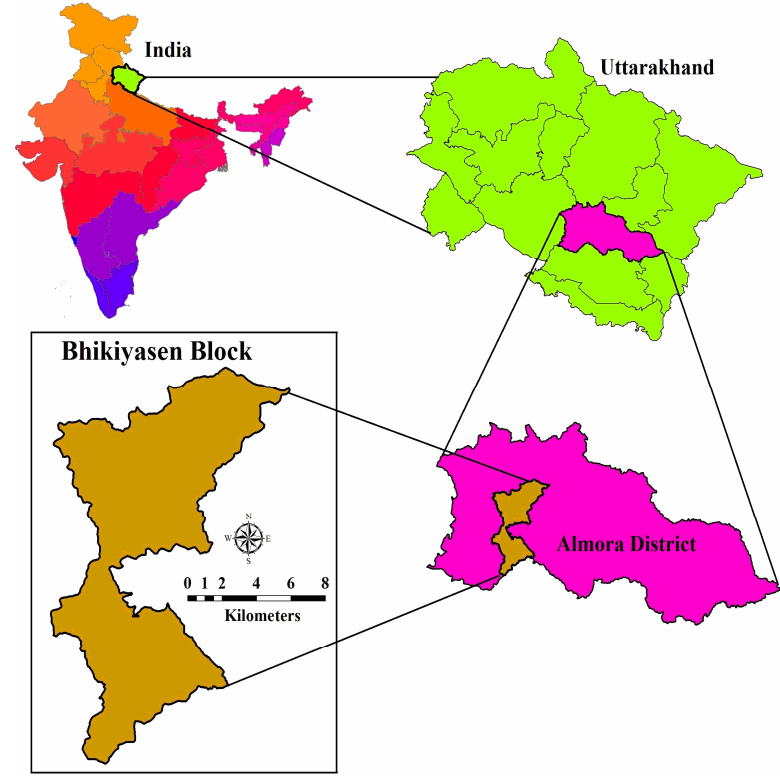

Fig. 1. Location of the study area.

\section{THEORY AND METHODOLOGY}

\subsection{Data collection and integration}

In order to develop site suitability map for built-up area development (Fig. 2), Cartosat-1 panchromatic stereoscopic satellite data at a resolution of $2.5 \mathrm{~m}$ was used. With the help of stereoscopic satellite data, a Digital Terrain Model (DTM) was created in LPS (Leica Photogrammetry Suite) 9.3 software, which was further used in the elaboratiuon of slope and aspect maps. High resolution Cartosat-1 satellite data was also used for generating road proximity, land use/cover and drainage proximity map. A geological map was obtained through Geological Survey of India, Dehradun. Land value buffer zones along the road were created using land value information acquired through Land Revenue Department of Almora. All these information layers were integrated and analysed using ArcGIS 9.3.

\subsection{Selection and preparation of criteria maps}

In this study, seven criteria were selected namely, slope; road proximity; land use/cover; land value; geological formation; drainage proximity and aspect for preparation of criteria maps.

\subsection{Suitability scoring / ranking and development of pairwise comparison matrix}

For suitability analysis it is necessary to give some score to each criteria as per their suitability for built-up area development. For this purpose, the pairwise comparison matrix using Saaty's nine-point weighing scale was applied (Table 1).
To develop a pairwise comparison matrix different criteria are required to create a ratio matrix. These pairwise comparisons are taken as input and relative weights are produced as an output.

\subsection{Normalized pairwise comparison matrix and computation of the criterion weights}

After the formation of pairwise comparison matrix, computation of the criterion weights is undertaken. The computation involves the following operations:

The computation involves the following operations:

a). Summation of the values in each column of the pairwise comparison matrix.

b). Division of each element in the matrix by its column total (the resulting matrix is referred to as normalized pairwise comparison matrix).

c). Computation of average values of elements in each row of the normalized matrix, i.e. dividing the sum of normalized scores of each row by the number of criteria. These average values provide an estimate of the relative weights of the criteria being compared (Malczewski, 1999).

It should be noted that for preventing bias thought criteria weighting, the Consistency Ratio (CR) was used.

\subsection{Estimation of the consistency ratio}

The next step is to calculate $\mathrm{CR}$ to measure how consistent the judgments were with respect to large samples of purely random judgments. The AHP deals with consistency explicitly because in making paired comparisons, just as in thinking, people do not have the intrinsic logical ability to always be consistent (Saaty, 1994).

For estimating consistency, the following operations are carried out: (a) Determination of the weighted sum vector by multiplying matrix of comparisons on the right by the vector of priorities to get a new column vector. Then, divide the first component of the new column vector by the first component of priorities vector, the second component of the new column vector by the second component of priorities vector, and so on. Finally, sum these values over the rows; (b) Determination of consistency vector by dividing the weighted sum vector by the criterion weights.

Once the consistency vector is calculated, it is required to compute values for two more terms known as lambda $(\lambda)$ and the consistency index (CI). The value of lambda is simply the average value of the consistency vector. The calculation of CI is based on the observation that $\lambda$ is always greater than or equal to the number of criteria under consideration (n) for positive, reciprocal 
matrices that is $\lambda=\mathrm{n}$, if the pairwise comparison matrix is consistent matrix. Accordingly, $\lambda$-n can be considered as a measure of the degree of inconsistency.

This measure can be normalized as follows:

$$
\mathrm{CI}=(\lambda-\mathrm{n}) /(\mathrm{n}-1)
$$

The term CI, referred to as Consistency Index, provides a measure of departure from consistency. To determine the correctness of CI, AHP compares it by
Random Index (RI), and the result is what we call CR, which can be defined as:

$$
\mathrm{CR}=\mathrm{CI} / \mathrm{RI}
$$

Random Index is the CI of a randomly generated pairwise comparison matrix of order 1 to 10 obtained by approximating random indices using a sample size of 500 (Saaty, 2000). Table 2 shows the value of RI sorted by the order of matrix.

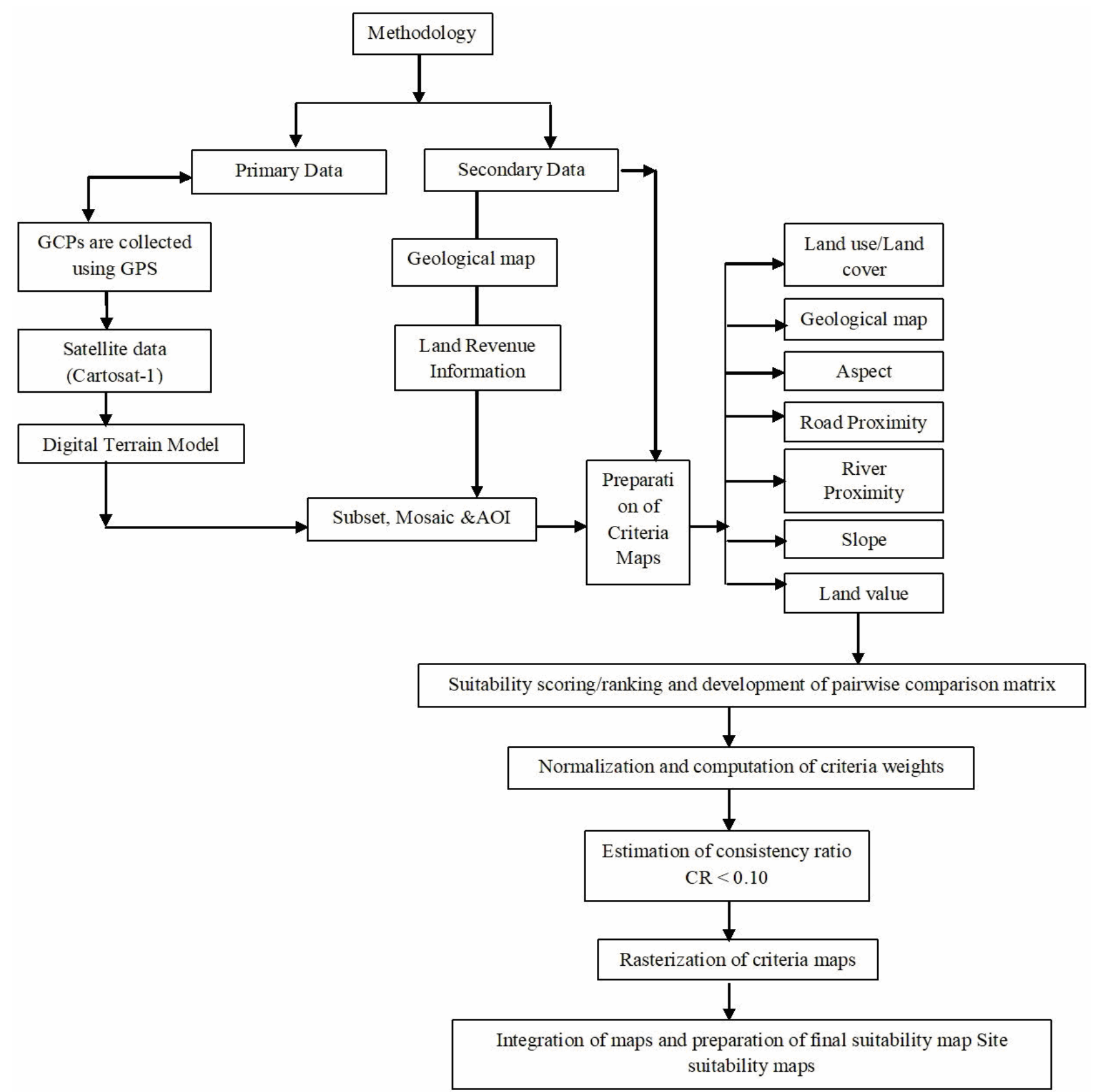

Fig. 2. Flow chart of research methodology.

The consistency ratio (CR) is designed in such a way that if $\mathrm{CR}<0.10$, the ratio indicates a reasonable level of consistency in the pairwise comparisons; if, however, $\mathrm{CR}>0.10$, then the values of the ratio are indicative of inconsistent judgments. In such cases, one should reconsider and revise the original values in the pairwise comparison matrix. 


\subsection{Rasterization of criteria maps}

Different criteria maps were converted into raster data environment for further analysis because in raster data format computation is less complicated than vector data format (Chang, 2006).

\subsection{Integration of maps and preparation of final suitability map}

After rasterization, these classified raster maps were integrated in raster calculator of ArcGIS and multiplying with weightage, and a final suitability map was prepared.

Table 1. Nine point weighting scale for pairwise comparison.

\begin{tabular}{c|ll}
$\begin{array}{c}\text { Intensity of } \\
\text { importance }\end{array}$ & \multicolumn{1}{c}{ Description } & \multicolumn{1}{c}{ Scoring/ranking } \\
\hline 1 & Equal importance & Lowest suitability \\
2 & Equal to moderate importance & Very low suitability \\
3 & Moderate importance & Low suitability \\
4 & Moderate to strong importance & Moderately low suitability \\
5 & Strong importance & Moderate suitability \\
6 & Strong to very strong importance & Moderate high suitability \\
7 & Very strong importance & High suitability \\
8 & Very to extremely strong importance & Very high suitability \\
9 & Extremely strong importance & Highest suitability
\end{tabular}

Source: Saaty, 1980.

Table 2. Random Index.

\begin{tabular}{c|ccccccccccc} 
Order Matrix & $\mathbf{1}$ & $\mathbf{2}$ & $\mathbf{3}$ & $\mathbf{4}$ & $\mathbf{5}$ & $\mathbf{6}$ & $\mathbf{7}$ & $\mathbf{8}$ & $\mathbf{9}$ & $\mathbf{1 0}$ \\
\hline R.I & 0.00 & 0.00 & 0.58 & 0.9 & 1.12 & 1.24 & 1.32 & 1.41 & 1.45 & 1.49
\end{tabular}

\section{RESULTS AND DISCUSSION}

\subsection{Site suitability analysis for urban development}

The effective criteria in site suitability analysis for urban development are briefly described below with their individual importance.

\subsubsection{Slope}

Slope is an important criterion in a hilly terrain for finding suitable sites for built-up development. Steep slopes are disadvantageous for construction works because slopes increase construction costs, limit maximum floor areas and contribute to erosion during construction and subsequent use. Slopes $<15$ degree are considered gentle and fair (Long, 2008) having a higher intensity of importance. Slopes greater than 15 degree have been classified as unsuitable because they increase construction costs (Fig. 3 and Table 3 ).

\subsubsection{Road proximity}

Easy road access helps movement and transportation in all directions. However, the construction of a new road is expensive, especially in hilly regions. So, efforts are made to locate the new built-up site near to any existing road, if feasible. Moreover, in order to find out better accessibility to the existing roads, buffer zones were created by taking a 100 meter distance from the road. Fig. 4 and Table 3 show the buffer zones and their intensity of importance for road proximity criterion.

\subsubsection{Land use/cover}

Land use/cover map of Bhikiyasen Block shows available land reflected by its uses categorized as built-up, barren, agricultural, river bed and forest. In this study, the existing built-up land is not suitable for future development works because, once a building is constructed, it remains there for minimum 50 to 75 years. The river bed is also not suitable for built-up area development. Thus, barren land is considered to be the most suitable for development purposes (Fig. 5 and Table 3).

\subsubsection{Land values}

Land value means the price of land at a given point in time based on its location. Land value varies from one location to another. Land values are high in the centre of a city whereas low in its periphery. Within a locality, accessibility has an impact on the land value as such values are high for the land nearer to roads. In the case of Bhikiyasen, the value of the land along the 
road is determined by the land revenue department of Almora district. At the time of this study, the approximate value of land located within o to $100 \mathrm{~m}$ distance to the road was of Rs. 2750 per $\mathrm{m}^{2}$, land located at a distance between $100 \mathrm{~m}$ to $500 \mathrm{~m}$ was of Rs. 1900 per $\mathrm{m}^{2}$ and land located at a distance of more than $500 \mathrm{~m}$ was of Rs. 1350 per $\mathrm{m}^{2}$. Thus the value decreases while going away from the road, but land with low value has highest potential of site suitability because of the low investment costs. Therefore, higher importance was given to land having lower financial values (Fig. 6 and Table 3). Since riverbed is not suitable for built-up area development, the revenue department has not calculated its land value due to which it was not considered in the study. At the same time, land under forest cover was also not considered because of the non-availability of land prices from the land revenue department of Almora district.

\subsubsection{Geological formation}

The geological formation of Bikyasen Block in the lesser Himalaya is part of the Almora Granite, Nagthat, Nathuwakhan and Saryu mica formation. Almora Granite mainly consists of gneiss. Nagthat formation presents the purple quartzite and green basic volcanic rock, while Nathuwakhan and Saryu mica formation mainly consist of white and purple quartzite interbedded with schist and mica-schist. According to the hardness of rock material, a highest importance was given to Almora Granite formation because it consists of gneiss which is harder and more resistant to erosion (Singh, 2003) as compared to Nagthat, Nathowakhan and Saryu mica formation (Fig. 7 and Table 3).

\subsubsection{Drainage proximity}
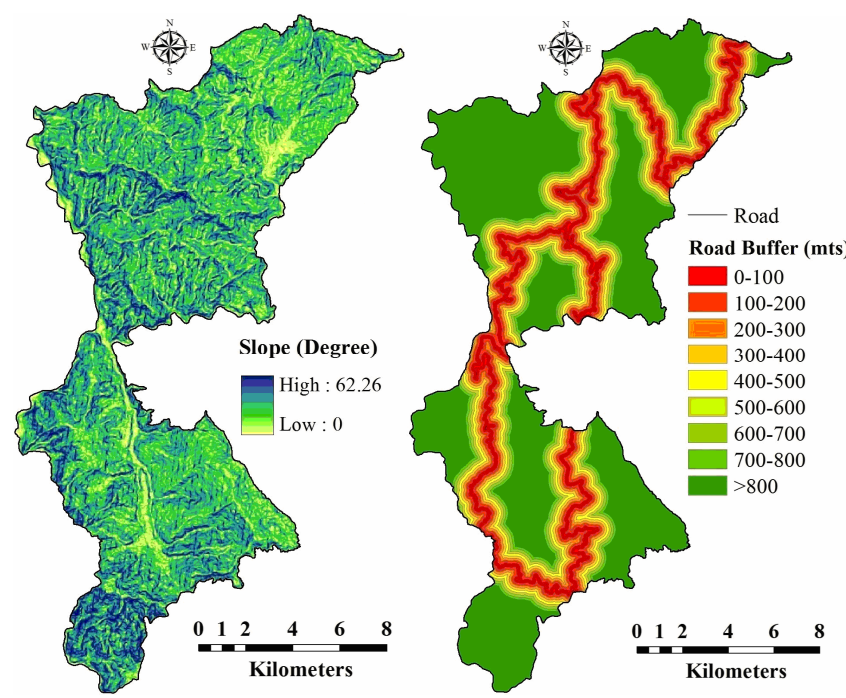

Fig. 3. Slope map.
Fig. 4. Buffer distance from a major roads.

Proximity to drainage is an important factor in hilly areas because it triggers landslide and flooding when runoff is higher. Studies have shown that the proximity to drainage lines of intensive gully erosion is an important factor controlling the occurrence of landslides (Gokceoglu and Aksoy, 1996; Pachauri et al., 1998; Gokceoglu, 2001). Considering these factors, a drainage proximity map was created in order to analyze the risk assessment. Areas nearer to the drainage lines are considered unsafe for built-up constructions and therefore higher importance was given to land areas which are farther from the drainage lines (Fig. 8 and Table 3).

\subsubsection{Aspect}

Aspect generally refers to the horizontal direction to which a mountain slope faces. In the northern hemisphere, north facing slopes receive very little heat from the sun in mid winter. Conversely, south facing slopes receive much more heat. Therefore, south facing slopes tend to be warmer than north facing slopes. In hilly areas, people prefer to build their houses on the sunny faced slopes. So, southern facing slopes have higher importance (Fig. 9 and Table 3). As far as east facing slopes are considered, they receive heat from the sun in the morning, when temperatures are colder, while west facing slopes receive heat from the sun in the afternoon, when it is warmer. Consequently, east facing slopes are colder than west facing slopes.

\subsection{Scoring of criteria}

The suitability scoring used in this study for each of the map and their category at 9 point scale are given in Table 3 .

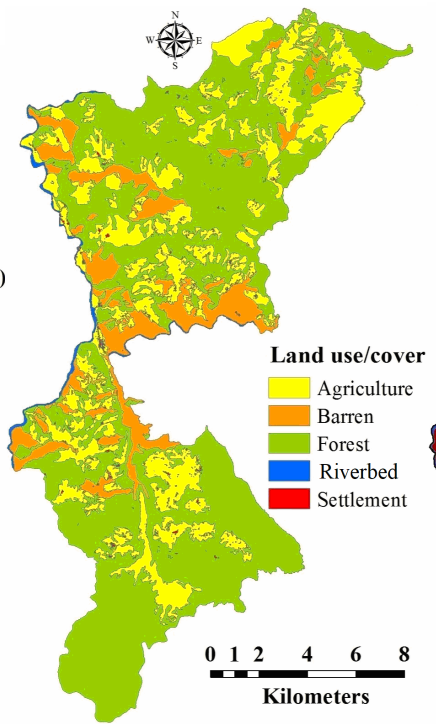

Fig. 5. Land Use/Land Cover map.

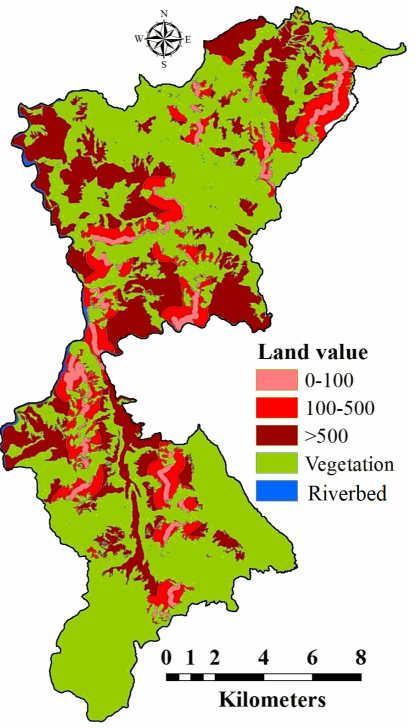

Fig. 6. Land value map. 


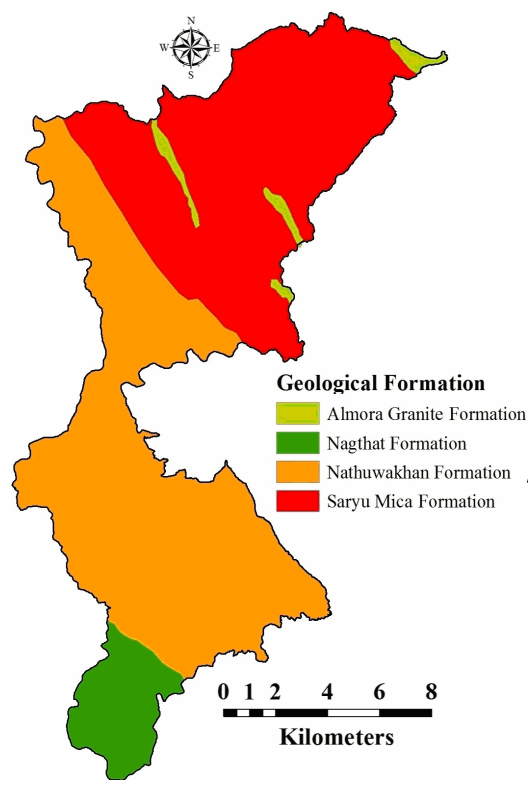

Fig. 7. Geological formation.

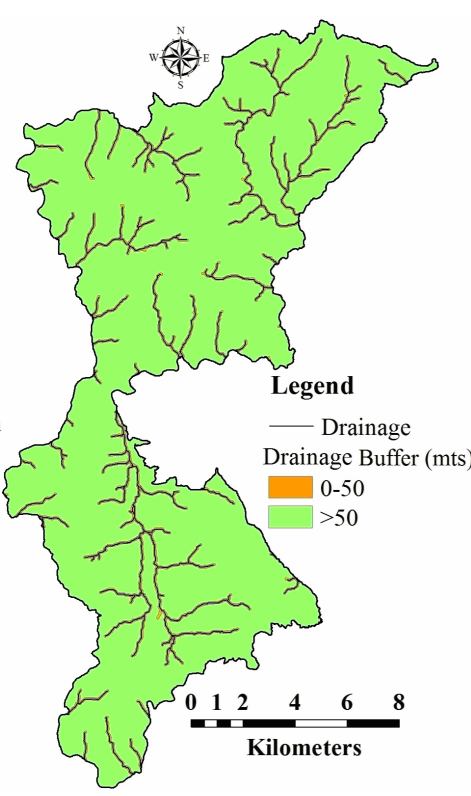

Fig. 8. Buffer distance from major drainage systems.

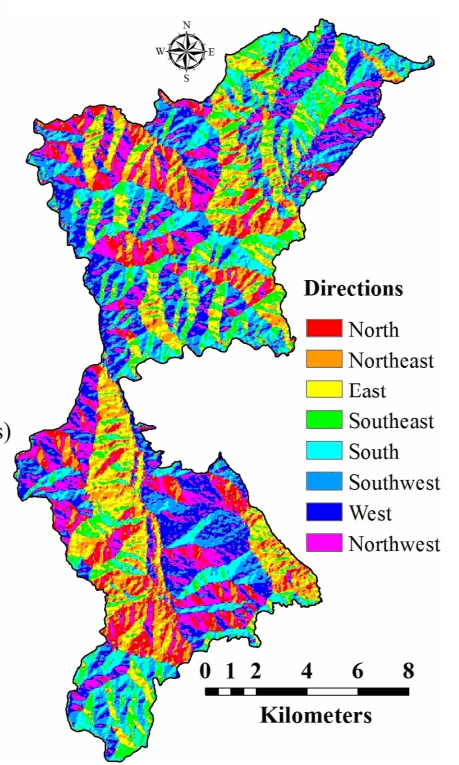

Fig. 9. Orientation of slopes.

Table 3. Suitability scoring of different criteria.

\begin{tabular}{|c|c|c|c|c|c|c|c|}
\hline Scoring/Ranking & $\begin{array}{c}\text { Slope } \\
\text { (Degree) }\end{array}$ & $\begin{array}{c}\text { Road } \\
\text { Proximity } \\
\text { (mts.) }\end{array}$ & $\begin{array}{l}\text { Land Use/ } \\
\text { Cover }\end{array}$ & $\begin{array}{l}\text { Land } \\
\text { Value } \\
\text { (mts.) }\end{array}$ & $\begin{array}{l}\text { Geological } \\
\text { Formation }\end{array}$ & $\begin{array}{c}\text { Drainage } \\
\text { Proximity } \\
\text { (mts.) }\end{array}$ & $\begin{array}{c}\text { Aspect } \\
\text { (Directions) }\end{array}$ \\
\hline 9 (Highest) & $<10$ & $0-100$ & Barren & $>500$ & $\begin{array}{c}\text { Almora } \\
\text { Granite } \\
\text { formation }\end{array}$ & $>50$ & South \\
\hline 8 (Very high) & $\ldots$ & $100-200$ & $\ldots$ & $\cdots$ & $\begin{array}{l}\text { Saryu Mica } \\
\text { formation }\end{array}$ & $\cdots$ & South-West \\
\hline 7 (High) & $10-20$ & $200-300$ & $\ldots$ & $100-500$ & $\ldots$ & $\ldots$ & South-East \\
\hline 6 (Moderate high) & $\ldots$ & $300-400$ & $\ldots$ & $\ldots$ & $\ldots$ & $\ldots$ & West \\
\hline 5 (Moderate) & $\cdots$ & $400-500$ & $\ldots$ & $<100$ & $\begin{array}{l}\text { Nagthat } \\
\text { formation }\end{array}$ & $\cdots$ & East \\
\hline 4 (Moderate low) & $20-30$ & $500-600$ & $\ldots$ & $\ldots$ & $\begin{array}{c}\text { Nathuwakhan } \\
\text { formation }\end{array}$ & $\cdots$ & North-West \\
\hline 3 (Low) & $30-40$ & $600-700$ & $\ldots$ & $\ldots$ & $\ldots$ & $\ldots$ & North-East \\
\hline 2 (Very low) & $40-50$ & $700-800$ & Agriculture & $\ldots$ & $\ldots$ & $\ldots$ & North \\
\hline 1 (Lowest) & $>50$ & $>800$ & Forest & $\ldots$ & $\ldots$ & $<50$ & $\ldots$ \\
\hline
\end{tabular}

\subsection{Development of pairwise comparison matrix and weighing of criteria}

With the help of the available criteria, a pairwise comparison matrix was developed (Table 4).

After the formation of ratio matrix, all criteria were normalised and weights were computed for each criteria using, pairwise comparison method (Table 5).

\subsection{Calculation of the consistency ratio}

It is required to check whether our comparisons are consistent. Table 6 shows the determination of weighted sum vector and consistency vector. Condition 1: $\lambda$ should be equal or greater than the number of criteria under consideration. The value calculated above satisfies this condition.

Calculation of $\mathrm{CI}$ :

$$
\begin{aligned}
& \mathrm{CI}=(\lambda-\mathrm{n}) / \mathrm{n}-1 \\
& =(7.13-7) /(7-1) \\
& =0.13 / 6 \\
& =0.02
\end{aligned}
$$

Calculation of CR, $\mathrm{CR}=\mathrm{CI} / \mathrm{RI}$

$=0.02 / 1.32($ Since $\mathrm{RI}=1.32$ for $\mathrm{n}=7)$ $=0.015$

Condition 2: CR $(=0.015)<0.10$ indicated a reasonable level of consistency in the pairwise comparisons. Therefore, the values obtained satisfy the said conditions, which denote that the weights obtained are agreeable. 


\subsection{Preparation of Land Suitability Map}

All seven criteria maps were converted into raster format, so that for each pixel, a score can be determined (Jain and Subbaiah, 2007). All the criteria maps were integrated and overlaid and final site suitability map (Fig. 10) was prepared by the following formula: Suitability map $=\Sigma$ [criteria map * weight]

Suitability index $=([$ Slope $] * 0.37)+([$ Road proximity $\left.]^{*} 0.25\right)+\left([\text { Land use/cover }]^{*} 0.15\right)+([$ Land value $\left.*^{*} 0.10\right)+\left([\text { Geological formation }]^{*} 0.06\right)+$ ([Drainage proximity $\left.]^{*} 0.04\right)+\left([\text { Aspect }]^{*} 0.03\right)$.

Table 4. Pairwise comparison matrix.

\begin{tabular}{|c|c|c|c|c|c|c|c|}
\hline \multirow[b]{2}{*}{ Criteria } & \multicolumn{7}{|c|}{ Pairwise comparison matrix } \\
\hline & Slope & $\begin{array}{c}\text { Road } \\
\text { proximity }\end{array}$ & $\begin{array}{c}\text { Land } \\
\text { use/cover }\end{array}$ & $\begin{array}{l}\text { Land } \\
\text { value }\end{array}$ & $\begin{array}{l}\text { Geological } \\
\text { formation }\end{array}$ & $\begin{array}{c}\text { River } \\
\text { proximity }\end{array}$ & Aspect \\
\hline Slope & 1 & 2 & 3 & 4 & 5 & 8 & 9 \\
\hline Road proximity & 0.50 & 1 & 2 & 3 & 4 & 5 & 8 \\
\hline Land use/cover & 0.33 & 0.50 & 1 & 2 & 3 & 4 & 5 \\
\hline Land value & 0.25 & 0.33 & 0.50 & 1 & 2 & 3 & 4 \\
\hline Geological formation & 0.20 & 0.25 & 0.33 & 0.50 & 1 & 2 & 3 \\
\hline River proximity & 0.12 & 0.20 & 0.25 & 0.33 & 0.50 & 1 & 2 \\
\hline Aspect & 0.11 & 0.12 & 0.20 & 0.25 & 0.33 & 0.50 & 1 \\
\hline Total & 2.51 & 4.40 & 7.28 & 11.08 & 15.83 & 23.50 & 32 \\
\hline
\end{tabular}

Table 5. Normalized pairwise comparison matrix and computation of criterion weights.

\begin{tabular}{|c|c|c|c|c|c|c|c|c|}
\hline \multirow[b]{2}{*}{ Criteria } & \multicolumn{7}{|c|}{ Normalised pairwise comparison matrix } & \multirow[b]{2}{*}{$\begin{array}{l}\text { Computation of } \\
\text { criterion weights } \\
(\mathbf{a}+\mathbf{b}+\mathbf{c}+\mathbf{d}+\mathbf{e}+\mathbf{f}+\mathbf{g}) / 7\end{array}$} \\
\hline & $\begin{array}{l}\text { Slope } \\
\text { (a) }\end{array}$ & $\begin{array}{c}\text { Road } \\
\text { proximity } \\
\text { (b) }\end{array}$ & $\begin{array}{c}\text { Land } \\
\text { use/cover } \\
\text { (c) }\end{array}$ & $\begin{array}{l}\text { Land } \\
\text { value } \\
\text { (d) }\end{array}$ & $\begin{array}{l}\text { Geological } \\
\text { formation } \\
\text { (e) }\end{array}$ & $\begin{array}{c}\text { River } \\
\text { proximity } \\
\text { (f) }\end{array}$ & $\begin{array}{l}\text { Aspect } \\
\text { (g) }\end{array}$ & \\
\hline Slope & 0.40 & 0.45 & 0.41 & 0.36 & 0.32 & 0.34 & 0.28 & 0.37 \\
\hline $\begin{array}{l}\text { Road } \\
\text { proximity }\end{array}$ & 0.20 & 0.23 & 0.27 & 0.27 & 0.25 & 0.21 & 0.25 & 0.25 \\
\hline $\begin{array}{l}\text { Land } \\
\text { use/cover }\end{array}$ & 0.13 & 0.11 & 0.14 & 0.18 & 0.19 & 0.17 & 0.16 & 0.15 \\
\hline $\begin{array}{l}\text { Land } \\
\text { value }\end{array}$ & 0.09 & 0.08 & 0.07 & 0.09 & 0.13 & 0.13 & 0.13 & 0.10 \\
\hline $\begin{array}{l}\text { Geological } \\
\text { formation }\end{array}$ & 0.08 & 0.06 & 0.05 & 0.05 & 0.06 & 0.09 & 0.09 & 0.06 \\
\hline $\begin{array}{l}\text { River } \\
\text { proximity }\end{array}$ & 0.05 & 0.04 & 0.03 & 0.03 & 0.03 & 0.04 & 0.06 & 0.04 \\
\hline Aspect & 0.04 & 0.03 & 0.03 & 0.02 & 0.02 & 0.02 & 0.03 & 0.03 \\
\hline Total & 1.00 & 1.00 & 1.00 & 1.00 & 1.00 & 1.00 & 1.00 & 1.00 \\
\hline
\end{tabular}

Table 6. Computation of consistency vector.

\begin{tabular}{|l|l|l|}
\hline Criterion & \multicolumn{1}{|c|}{ Weighted sum vector } & \multicolumn{1}{|c|}{$\begin{array}{c}\text { Consistency } \\
\text { vector }\end{array}$} \\
\hline Slope & {$[(1)(0.37)+(2)(0.25)+(3)(0.15)+(4)(0.10)+(5)(0.06)+(8)(0.04)+(9)(0.03)]$} & $2.61 / 0.37=7.05$ \\
\hline Road proximity & {$[(0.50)(0.37)+(1)(0.25)+(2)(0.15)+(3)(0.10)+(4)(0.06)+(5)(0.04)+(8)(0.03)]$} & $1.72 / 0.25=6.88$ \\
\hline Land use/cover & {$[(0.33)(0.37)+(0.50)(0.25)+(1)(0.15)+(2)(0.10)+(3)(0.06)+(4)(0.04)+(5)(0.03)]$} & $1.09 / 0.15=7.27$ \\
\hline Land value & {$[(0.25)(0.37)+(0.33)(0.25)+(0.50)(0 . .15)+(1)(0.10)+(2)(0.063)+(3)(0.04)+(4)(0.03)]$} & $0.71 / 0.10=7.10$ \\
\hline $\begin{array}{l}\text { Geological } \\
\text { formation }\end{array}$ & {$[(0.20)(0.37)+(0.25)(0.25)+(0.33)(0.15)+(0.50)(0.10)+(1)(0.06)+(2)(0.04)+(3)(0.03)]$} & $0.46 / 0.06=7.67$ \\
\hline River proximity & {$[(0.10)(0.37)+(0.20)(0.25)+(0.25)(0.15)+(0.33)(0.10)+(0.50)(0.06)+(1)(0.44)+(2)(0.03)]$} & $0.29 / 0.04=7.25$ \\
\hline Aspect & {$[(0.11)(0.37)+(0.12)(0.25)+(0.20)(0.15)+(0.25)(0.10)+(0.33)(0.06)+(0.50)(0.04)+(1)(0.0$} & $0.20 / 0.03=6.67$ \\
\hline
\end{tabular}

Calculation of lambda $(\lambda)=(7.05+6.88+7.27+7.10+7.67+7.25+6.67 / 7)=7.13$

Note: Lambda $(\lambda)$ is the average of consistency vector.

The site suitability map (Fig. 10) reveals that the study area was divided into five different suitability categories. The area under very high, high, moderate, less and least suitable lands stand at $4.41 \mathrm{~km} 2$ (2.19\%), 
$36.05 \mathrm{~km}^{2}$ (17.93\%), $57.4 \mathrm{~km}^{2}$ (28.55\%), $81.73 \mathrm{~km}^{2}$ (40.65\%) and $21.45 \mathrm{~km}^{2} \quad(10.67 \%)$ (Table 7). Approximately $51 \%$ of the total area falls under less and least suitability categories. Only $20.12 \%$ of land falls under highly and very highly suitable categories.

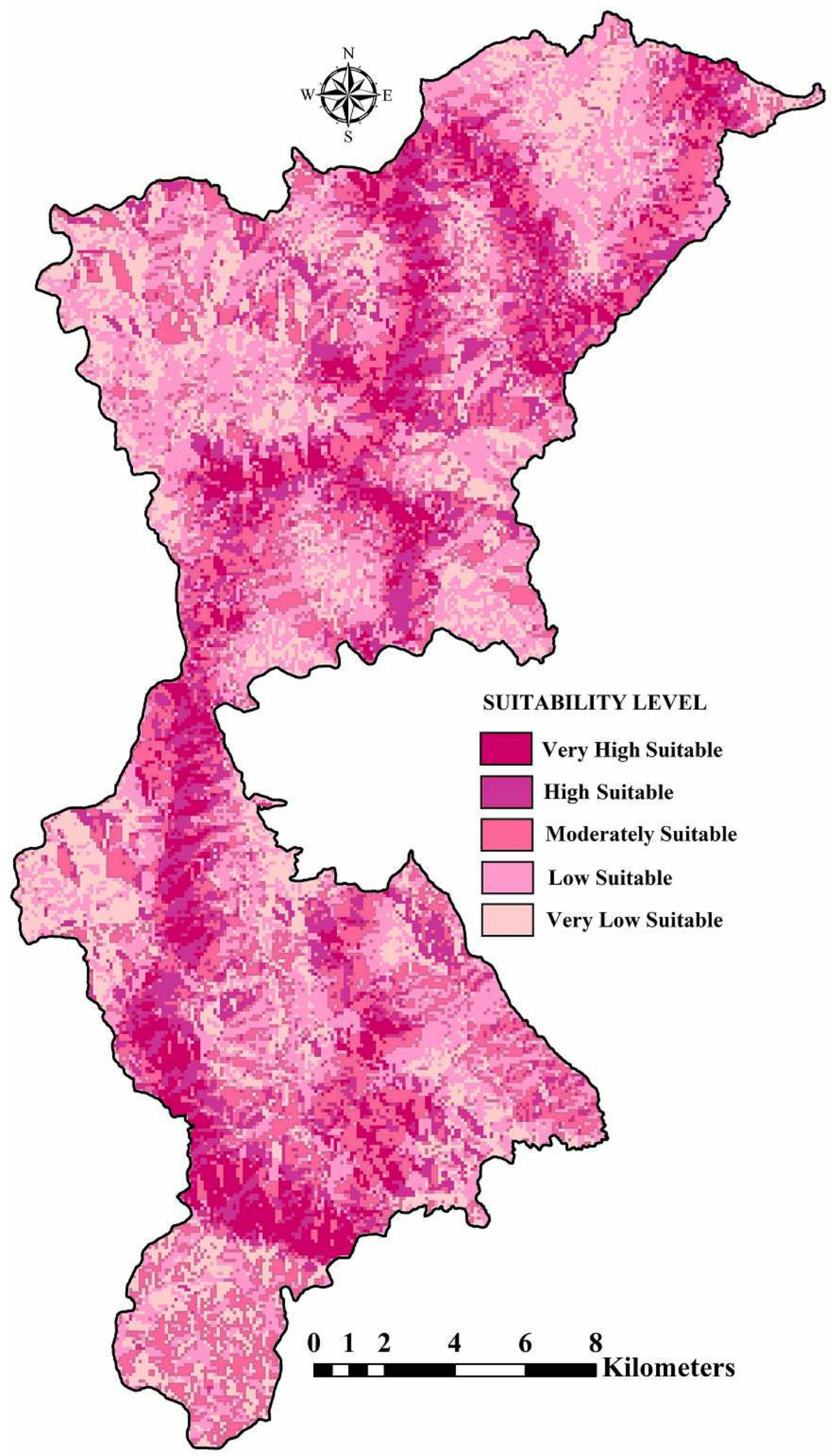

Fig. 10. Final Site Suitability Map based on different criteria weights and their scores.

The site suitability map (Fig. 10) reveals that the study area was divided into five different suitability categories. The area under very high, high, moderate, less and least suitable lands stand at $4.41 \mathrm{~km} 2$ (2.19\%), 
$36.05 \mathrm{~km}^{2}$ (17.93\%), $57.4 \mathrm{~km}^{2}$ (28.55\%), $81.73 \mathrm{~km}^{2}$ (40.65\%) and $21.45 \mathrm{~km}^{2}$ (10.67\%) (Table 7).

Table 7. Area under different suitability categories.

\begin{tabular}{|l|r|r|}
\hline \multicolumn{1}{|c|}{$\begin{array}{c}\text { Suitability } \\
\text { categories }\end{array}$} & Area $\left.\mathbf{( k m}^{\mathbf{2}}\right)$ & \multicolumn{1}{c|}{ Area $\mathbf{( \% )}$} \\
\hline Very high suitable & 4.41 & 2.19 \\
\hline High suitable & 36.05 & 17.93 \\
\hline Moderately suitable & 57.4 & 28.55 \\
\hline Low suitable & 81.73 & 40.65 \\
\hline Very low suitable & 21.45 & 10.67 \\
\hline
\end{tabular}

Approximately $51 \%$ of the total area falls under less and least suitability categories. Only $20.12 \%$ of land falls under highly and very highly suitable categories.

\section{CONCLUSIONS}

In this study an integrated approach of GIS and AHP was employed in order to identify alternative potential sites for built-up area development. This method not only that offers a scientific way to decide locations, but also provides a methodology for assessing the suitability of alternative sites as well as cost-benefit analysis for the same. The high demand of land resources increases the importance of land use planning studies. Traditional methods are costly and timeconsuming while involving failures in handling various criteria and inconsistency of expert opinions in judging the relative importance of each criterion. This study basically aims to develop a decision support system using analytical hierarchy method as one of the multi criteria evaluation methods. As a powerful tool, spatial analytical hierarchy method assists decision-makers to determine the most suitable areas for different land uses. The study reveals that approximately more than $50 \%$ (i.e. least suitable and less suitable) of the study area is unsafe and unsuitable for construction works. It is also evident that only $20.12 \%$ (i.e. very highly suitable and highly suitable) of the study area is safe for built-up constructions. To sum up, this model can also encourage public participation in the decision-making process and assist various planners and authorities to formulate suitable plans for sustained development of the region, thus reducing future environmental hazards on the hillside development. In addition, accessibility provides a key role in the economic development of any region. Unplanned road network can be harmful to the economy and environment. If hillside development can be safe from environmental threats, then it will be more attractive for people and can contribute to the economy of the region.

\section{ACKNOWLEDGEMENTS}

The authors are thankful to the NRDMS Division, Kumaun University, SSJ Campus, Almora, 38
Uttarakhand for their assistance and constant technical support.

\section{REFERENCES}

Aly M. H., Giardino J. R., Klein A. G. (2005), Suitability Assessment for New Minia City, Egypt: A GIS Approach to Engineering Geology. Environmental Engineering and Geosciences, 3, 259-269. DOI: https://doi.org/10.2113/11.3.259

Banai-Kashani R. (1989), New Method for site suitability analysis: the analytical hierarchy process. Environmental Management, 13(6), 685-698. DOI: https://doi.org/10.1007/BFo1868308

Burrough P. A., MacMillan R. A., Deursen W. V. (1992), Fuzzy classification methods for determining land suitability from soil profile observations and topography. Journal of Soil Science, 43, 193-210. DOI: https://doi.org/10.1111/j.1365-2389.1992.tbo0129.x

Chang K. T. (2006), Introduction to Geographic Information System. Tata McGraw Hill. New Delhi. ISBN: 978-0-07-310171-2.

Eastman J. R., Kyem P. A. K., Toledano J. (1993), A procedure for multiobjective decision making in GIS under conditions of convicting objectives: In Proceedings of European Conference on Geographical Information Systems, EGIS'93 (Utrecht: EGIS Foundation), 438-448.

Gokceoglu C., Aksoy H. (1996), Landslide susceptibility mapping of the slopes in the residual soils of the Mengen region (Turkey) by deterministic stability analyses and image processing techniques. Engineering Geology, 44, 147-161. DOI: https://doi.org/10.1016/ So013-7952(97)81260-4

Gokceoglu C. (2001), Discussion on "Landslide hazard zonation of the Khorshrostam area, Iran" by A. Uromeihy and M.R. Mahdavifar. Bulletin of Engineering Geology and the Environment, 58, 207213. DOI: https://doi.org/10.1007/s100640050076

Jain K., Subbaiah V.Y. (2007), Site suitability analysis for urban development using GIS. Journal of Applied Science, 7(18), 2576-2583. DOI: https:// scialert.net/abstract/?doi=jas.2007.2576.2583

Jankowski P. (1995), Integrating geographical information systems and multiple criteria decision making methods. International Journal of Geographic Information System, 9, 251-273. DOI: https://doi.org/ 10.1080/02693799508902036

Janssen R., Rietveld P. (1990), Multi-criteria analysis and geographical information systems: an application to agricultural land use in The Netherlands. In: Scholten, H.J., Stillwell, J.C.H. (eds) Geographical Information Systems for Urban and Regional Planning, Kluwer Academic Publisher, The Netherlands, 129-139. DOI: https://doi.org/10.1007/978-94-017-1677-2_12

Kinoshita E. (2005), Why we need AHP/ANP Instead of Utility Theory in Today's Complex World- AHP from 
the Perspective of Bounded Rationality, ISAHP. URL: http://www.isahp.org/2005Proceedings/Papers/Kinos hitaE_AHP\&ANPvsUtilityTheory.pdf. Accessed on 05.08.2019.

Kumar M., Shaikh V. R. (2012), Site Suitability Analysis for Urban Development Using GIS Based Multicriteria Evaluation Technique: A Case Study of Mussoorie Municipal Area, Dehradun District, Uttarakhand. Journal of Indian Society of Remote Sensing, 41(2), 417-424. DOI: https://doi.org/10.1007/ S12524-012-0221-8

Kumar M., Biswas V. (2013), Identification of Potential Sites for Urban Development Using GIS Based Multi Criteria Evaluation Technique. A Case Study of Shimla Municipal Area, Shimla District, Himachal Pradesh, India. Journal of Settlements and Spatial Planning, 4(1), 45-51.

Kumar M., Pravesh R., Tripathi D. K. (2014), Comparison of Weighting Assessment Techniques and its Integration with GIS-Based Multicriteria Decision Making. Proceedings of the National Academy of Sciences, India Section A: Physical Sciences, 85(1), 197209. DOI: https://doi.org/10.1007/s40010-014-0186-9 Li A. N., Wang A. S., Liang S., Zhou W. (2006), Eco-environmental Vulnerability Evaluation in Mountainous Region Using Remote Sensing and GIS-A Case Study in the Upper Reaches of Minjiang River, China. Ecological Modelling, 192, 175-187. DOI: https://doi.org/10.1016/j.ecolmodel.2005.07.005

Liu Y., Lv X., Qin X., Guo H., Yu Y., Wang J., Mao G. (2007), An Integrated GIS-based Analysis System for Land-use Management of Lake Areas in Urban Fringe. Landscape and Urban Planning, 82, 233246. DOI: https://doi.org/10.1016/j.landurbplan. 2007. 02.012
Long N. T. (2008), Landslide Susceptibility Mapping of The Mountainous Area in A Luoi District, Thua Thien Hue Province, Vietnam. Unpublished Doctor in Engineering Thesis, Department of Hydrology and Hydraulic Engineering, Vrije Universiteite, Brussel, 255.

Malczewski J. (1999), GIS and Multi-criteria Decision Analysis. Wiley, New York. ISBN: 978-0-471-32944-2.

Pachauri A. K., Gupta P. V., Chander R. (1998), Landslide zoning in a part of the Garhwal Himalayas. Environmental Geology, 36(3-4), 325-334. DOI: https://doi.org/10.1007/soo2540050348

Pereira J. M. C., Duckstein L. (1993), A multiple criteria decision-making approach to GIS-base land suitability evaluation. International Journal of Geographic Information System, 7, 407-424. DOI: https://doi.org/10.1080/02693799308901971

Saaty T. L. (1980), The analytic hierarchy process. McGraw-Hill. New York. ISBN-13: 978-0-07-054371-3

Saaty T. L. (1994), Fundamentals of Decision Making and Priority Theory with The Analytic Hierarchy Process. RWS Publications. Pittsburgh. ISBN: 978-096-203176-2.

Saaty T. L. (2000), Fundamentals of Decision Making and Priority Theory. RWS Publications. Pittsburgh. ISBN: 978-0-96-203176-2.

Siddiqui M. Z., Everett J. W., Vieux B. E. (1996), Landfill siting using geographic information systems: a demonstration. Journal of Environmental Engineering, 122(6), 515-523. DOI: https://doi.org/10.1061/(ASCE) 0733-9372(1996)122:6(515)

Singh S. (2003), Physical Geography. Prayag Pustak Bhawan. Allahabad. ISBN: 978-8-18-653929-3. 